\title{
HEART DISEASE ATTRIBUTED TO OCCUPATIONAL NOISE, VIBRATION AND OTHER CO-EXPOSURE: SELF-REPORTED POPULATION-BASED SURVEY AMONG BULGARIAN WORKERS
}

\author{
CHOROBY SERCA ZWIAZANE Z ZAWODOWYM NARAŻENIEM \\ NA HAŁAS, DRGANIA I INNE CZYNNIKI WSPÓŁWYSTĘPUJĄCE - \\ POPULACYJNE BADANIE ANKIETOWE BUŁGARSKICH PRACOWNIKÓW
}

Medical University of Plovdiv, Plovdiv, Bulgaria

Faculty of Public Health

${ }^{1}$ Department of Hygiene and Ecomedicine

${ }^{2}$ Department of Health Management and Healthcare Economics

\begin{abstract}
Background: Cardiovascular disease (CVD) is the main mortality cause worldwide. Noise and vibration are considered to be occupational risk factors, but little is known about their cardiovascular effects in Bulgaria in terms of gender and various professional groups. The aim of this study has been to investigate the risk of prevalent CVD, associated with occupational noise and vibration exposure. Material and Methods: We conducted a secondary analysis of the data from 3 waves of the European Working Conditions Survey (EWCS) 2001-2010 - a nationally-representative cross-sectional questionnaire survey covering 3149 workers aged $\geq 15$ years in Bulgaria. Data on self-reported heart disease were linked to self-reported occupational noise and vibration, adjusting for other factors. Results from the 3 waves were pooled together using the inverse variance heterogeneity (IVhet) meta-analysis. Results: For noise, the risk was elevated among women (relative risk (RR) $=1.26,95 \%$ confidence interval (CI): $0.53-3.01)$, but not men $(\mathrm{RR}=0.49,95 \% \mathrm{CI}: 0.14-1.65)$. Long-term workers had $\mathrm{RR}=1.01,95 \% \mathrm{CI}$ : $0.60-1.69$. For vibration, the risk was increased in all participants. It was higher among men $(\mathrm{RR}=2.56,95 \% \mathrm{CI}$ : $1.60-4.09)$ than it was among women $(\mathrm{RR}=1.32,95 \% \mathrm{CI}: 0.77-2.27)$. Among long-term, industrial, and service workers it was $\mathrm{RR}=1.56,95 \% \mathrm{CI}: 1.02-2.40$; $\mathrm{RR}=1.10,95 \% \mathrm{CI}: 0.61-1.98$, and $\mathrm{RR}=1.18,95 \% \mathrm{CI}: 0.57-2.46$, respectively. Conclusions: Occupational vibration was a risk factor for prevalent heart disease in Bulgaria. Noise was an alleged risk factor only among long-term workers and women. Med Pr 2016;67(4):435-445
\end{abstract}

Key words: occupational exposure, gender, noise, cardiovascular disease, heart disease, vibration

\section{STRESZCZENIF}

Wstęp: Choroby układu sercowo-naczyniowego są główną przyczyną zgonów na świecie. Z kolei hałas i wibracje uznaje się za czynniki ryzyka zawodowego, ale niewiele wiadomo na temat ich wpływu na układ krążenia u mieszkańców Bułgarii z uwzględnieniem płci i różnych grup zawodowych. Celem pracy była ocena ryzyka występowania chorób układu krążenia związanego z zawodowym narażeniem na hałas i drgania. Materiał i metody: Wykonano retrospektywną analizę danych z 3 etapów (lat 2001-2010) Europejskiego Badania Warunków Pracy (European Working Conditions Survey - EWCS). Analiza obejmowała wyniki badania ankietowego reprezentatywnej próby - 3149 bułgarskich pracowników w wieku $\geq 15$ lat. Po wprowadzeniu poprawki na inne badane czynniki okazało się, że istnieje związek między zgłaszanymi w ankiecie przypadkami chorób serca a narażeniem na hałas i drgania w miejscu pracy. Wyniki 3 etapów badania połączono, dokonując metaanalizy z zastosowaniem metody ważenia przez odwrotność wariancji (inverse variance heterogeneity - IVhet). Wyniki: W przypadku hałasu ryzyko występowania chorób układu krążenia było podwyższone u kobiet (ryzyko względne (relative risk - RR) = 1,26; 95-procentowy przedział ufności (95\% confidence interval - 95\% CI): 0,53-3,01, ale nie wśród mężczyzn (RR = 0,49; 95\% CI: 0,14-1,65). U pracowników o długim stażu pracy ryzyko względne wynosiło 1,01 (95\% CI: 0,60-1,69). W przypadku wibracji RR było zwiększone u wszystkich badanych, ale bardziej u mężczyzn $(\mathrm{RR}=2,56 ; 95 \% \mathrm{CI}: 1,60-4,09)$ niż u kobiet $(\mathrm{RR}=1,32 ; 95 \%$ CI: 0,77-2,27). Wśród pracowników o długim stażu pracy ryzyko względne wynosiło 1,56 (95\% CI: 1,02-2,40), u zatrudnionych w przemyśle - 1,10 (95\% CI: 0,61-1,98), a u pracujących w sektorze usług - 1,18 (95\% CI: 0,57-2,46). Wnioski: Narażenie na drgania w miejscu pracy w Bułgarii było czynnikiem zwiększonego ryzyka chorób serca. Natomiast narażenie na hałas prawdopodobnie było tym czynnikiem tylko wśród kobiet i robotników o długim stażu pracy. Med. Pr. 2016;67(4):435-445

Słowa kluczowe: narażenie zawodowe, płeć, hałas, choroba układu sercowo-naczyniowego, choroba serca, drgania

Corresponding author / Autor do korespondencji: Angel M. Dzhambov, Medical University of Plovdiv, Faculty of Public Health, Department of Hygiene and Ecomedicine, 15-A Vassil Aprilov Boulevard, 4002 Plovdiv, Bulgaria, e-mail: angelleloti@gmail.com Received: January 1, 2016, accepted: March 17, 2016 


\section{INTRODUCTION}

Cardiovascular disease (CVD) is the main mortality cause in the world, and its prevalence is projected to increase in future decades [1,2]. Occupational noise and vibration are often associated and found as coexposure in industry. They are still prevalent across Europe and are considered risk factors for the CVD. According to the 6th European Working Conditions Survey (EWCS), 27.6\% and 20.3\% of European workers in 2015 were exposed to excessive noise and vibration, respectively, for at least a quarter of the time [3].

Noise is a general environmental stressor for the neuro-endocrine system, leading to activation of the sympathetic-adrenal-medullary system, increase in plasma cortisol and catecholamine levels, vasoconstriction, elevated blood pressure and, as a result, the CVD [4]. Meta-analyses demonstrated an elevated risk for hypertension, higher blood pressure and electrocardiography (ECG) abnormalities among occupationally exposed workers [5-7]. Several other studies suggested higher risk of ischemic heart disease as well $[8,9]$. Some Bulgarian studies also found an association between self-reported noise at work and ischemic heart disease $[10,11]$.

Vibration, on the other hand, may be classified as hand-arm vibration and whole-body vibration [12]. It may lead to the CVD through peripheral vasoconstriction, endothelial dysfunction and raised blood pressure; vibration is also associated with adverse effect on the rheological properties of blood, triglyceride and cholesterol levels, and heart-rate variability [11,13-15]. However, few field studies have linked it to the CVD.

The prevalence of ischemic heart disease among exposed miners was higher than among non-exposed controls [16], and Björ et al. found higher odds of incident myocardial infarction among workers exposed to hand-arm and whole-body vibration [15]. With respect to hypertension, Idzior-Walus found higher mean blood pressure and hypertension prevalence among men co-exposed to noise and vibration [17]. In Bulgaria, the evidence is also scarce. During the period 19821987 higher prevalence of hypertension and ischemic heart disease was observed among blue-collar workers (men and women) exposed to vibration, in comparison to non-exposed white-collar workers [18], while Dimitrova and Karaslavova reported elevated odds only among women [11].

All of those previous studies have important limitations. They focused on blue-collar male workers and, as a result, little is known about the effects among women and white-collar workers. Noise and vibration have been studied mostly separately without adjustment for other occupational factors related to the CVD, such as occupational smoke and dust [19], heavy lifting [20], extreme temperatures [21], working hours [22] and shift work [23]. Furthermore, the evidence from Bulgaria is largely insufficient, outdated, and lacks adequate adjustments of the models to draw conclusions about the risk nowadays. Thus, the aim of this study has been to investigate the risk of prevalent CVD, associated with occupational noise and vibration exposure in a representative sample of Bulgarian workers.

\section{MATERIAL AND METHODS}

\section{Data source}

This study used data for Bulgaria from the 3rd (2001), 4th (2005) and 5th (2010) waves of the European Working Conditions Survey (EWCS). In brief, the EWCS is a pan-European cross-sectional representative questionnaire-based survey conducted every 5 years by the European Foundation for the Improvement of Living and Working Conditions. It covers the active population aged $\geq 15$ years. Information on sociodemographic, occupational, and health factors were collected through face-to-face interviews at participants' home. The EWCS employed multi-stage stratified random sampling. Response rates for Bulgaria were $\geq 65 \%$.

The EWCS dataset was provided by the UK Data Service after we had filled an application and were granted access [24]. The organizations conducting the EWCS adhered to the international standards in research ethics. Data was anonymized during the process of their collection and participants gave informed consent. Therefore no approval by institutional review board was necessary for our secondary analysis.

Because the exact questions and their quality varied across the three waves of the EWCS, we used only variables pertinent to all three of them to make the results comparable.

\section{Outcome assessment}

Cardiovascular disease status was elicited from the question: "Does your work affect your health: heart disease?".

\section{Exposure assessment}

Self-reported occupational exposures to noise, vibration, smoke/fumes/powder/dust, high temperatures, 
low temperatures, and heavy lifting were measured with the questions:

Are you exposed at work to noise so loud that you would have to raise your voice to talk to people?

Vibrations from hand tools, machinery, etc.?

High temperatures which make you perspire even when not working?

Low temperatures whether indoors or outdoors?

Breathing in smoke, fumes, powder or dust, etc.?

Does your main paid job involve carrying or moving heavy loads?

Participants were classified as exposed if they reported exposure to the respective factor for at least half of the time spent at work [10]. The validity of selfreported noise and vibration among blue-collar workers was ascertained by comparing participants' ratings with available job-exposure data about objectively measured exposure for some titles $[25,26]$.

\section{Additional explanatory factors}

We extracted data on age, gender, number of household members, age at which full-time education was finished, working shift work or not, number of working hours/week, and number of years of working for the current company/organization. Occupational categories according to the Statistical Classification of Economic Activities in the European Community (NACE), revision 1.1 (2002) were collapsed into agriculture, hunting and forestry + fishing (codes A-B), industry (codes $\mathrm{C}-\mathrm{F}$ ), services - excluding public administration (codes $\mathrm{G}-\mathrm{K}$ ) and public administration and defense, other services (codes I-Q).

\section{Data analysis}

The data was screened for missing rates. Missing values were subjected to list-wise deletion in each analysis. Owing to the different selection probabilities, the analyses were weighted by the country level sampling weight [24]. Descriptive statistics were computed to explore the structure of the data and univariate relationships between key factors.

To estimate the multivariate relative risk of prevalent heart disease we employed generalized linear regression with binomial distribution or, in the case of non-convergence, Poisson regression with robust variance estimator [27].

Causal diagrams were set up to determine the necessary adjustments in the multivariate models using DAGitty v. 2.3 [28]. We were interested in the total effect of self-reported occupational noise and vibration since the direct effect, albeit of theoretical importance, is not observed per se in real life. In order to investigate the complex imbrication of various environmental and individual risks for the CVD, even factors that we had no data on (i.e., diet, physical activity, heredity, body mass index, residential exposures) were included in the diagrams. Their absence, however, was found to be acceptable, since they were necessary covariates for the direct rather than the total effect model. The suggested minimal sufficient set of covariates for estimating the total effect of self-reported occupational noise/vibration on heart disease included: age, gender, workweek hours, length of service, shift work, and other co-exposures. We additionally forced into the models (as proxies for participants' socioeconomic status) the number of household members and the age at which full-time education was finished.

Regression models were run on the total sample and separately on subsamples defined by gender, length of service and occupational category. The dataset from each wave of the EWCS was treated as a separate study and wave-specific differences were assumed to be due to random error, rather than being true risk differences. Therefore the multivariate models were first run within each of the three datasets, and the results were then pooled together using inverse variance heterogeneity meta-analysis [29].

Results were considered statistically significant at $\mathrm{p}<0.05$ and precise if the upper-to-lower 95\% confidence limits ratio (CLR) was in the ballpark of 1.00 3.00 [30]. Data was processed with the Statistical Package for the Social Sciences (SPSS) 17 and the "binreg" command in STATA (Collage Station, Texas).

\section{RESULTS}

Sample sizes for the 3 waves of the EWCS were 1000, 1135 and 1014, respectively. The highest percentage of missing data was within the variable "heart disease" - 31.1\% in $2001,54 \%$ in 2005 and $0.1 \%$ in 2010 . Owing to this, sample sizes differed across the analyses.

The Table 1 reports participants' characteristics in the 3 waves of data collection. Men were slightly more than women, most participants were at 16-19 years of age when they finished their full-time education, and their household consisted of about 3 members. Most participants worked for little over $40 \mathrm{~h} /$ week and for a mean of 8 years in their current organization; $1 / 4$ were shift workers. The Figure 1 presents the change in the proportion of workers reporting occupational expo- 
sure to different physical and chemical factors during the period 2001-2010. The proportion of workers exposed to smoke/fumes/powder/dust followed a downward trend, but there was not substantive change in the other factors. Self-reported vibration exposure

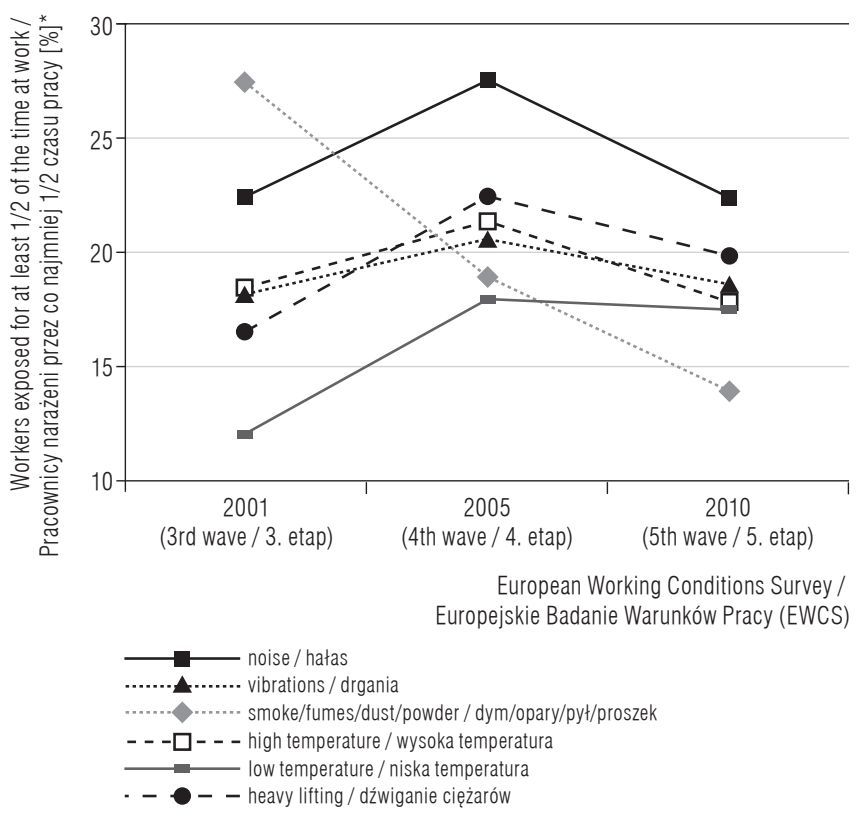

* Percentages are weighted / Wartości procentowe są ważone.

Fig. 1. Workers reporting occupational exposure to different physical and chemical factors, Bulgaria, in years 2001, 2005, and 2010

Ryc. 1. Pracownicy zgłaszający zawodowe narażenie na różne czynniki fizyczne i chemiczne w Bułgarii w latach 2001, 2005 i 2010

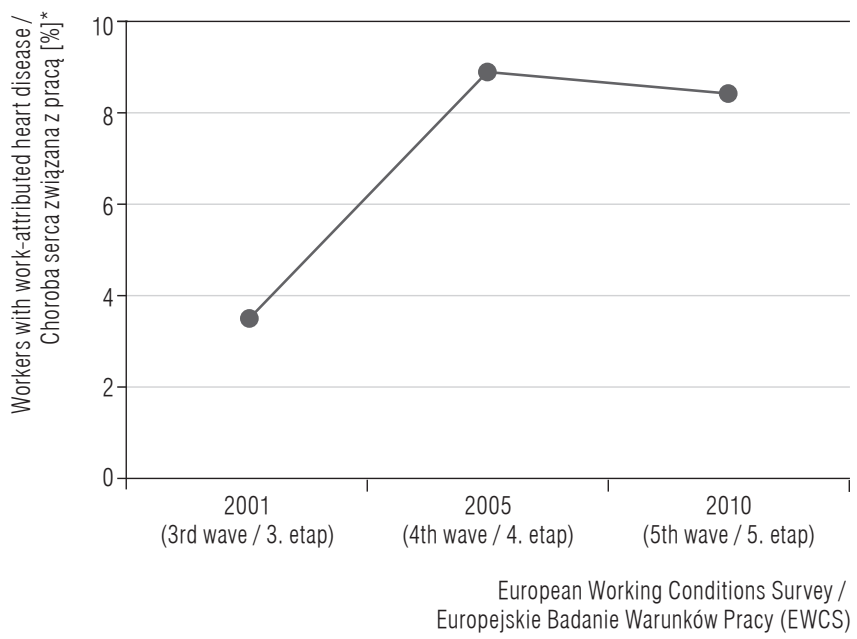

* Percentages are weighted / Wartości procentowe są ważone.

Fig. 2. Workers reporting work-attributed heart disease, Bulgaria, in years 2001, 2005, and 2010

Ryc. 2. Pracownicy zgłaszający chorobę serca związaną z pracą w Bułgarii w latach 2001, 2005 i 2010

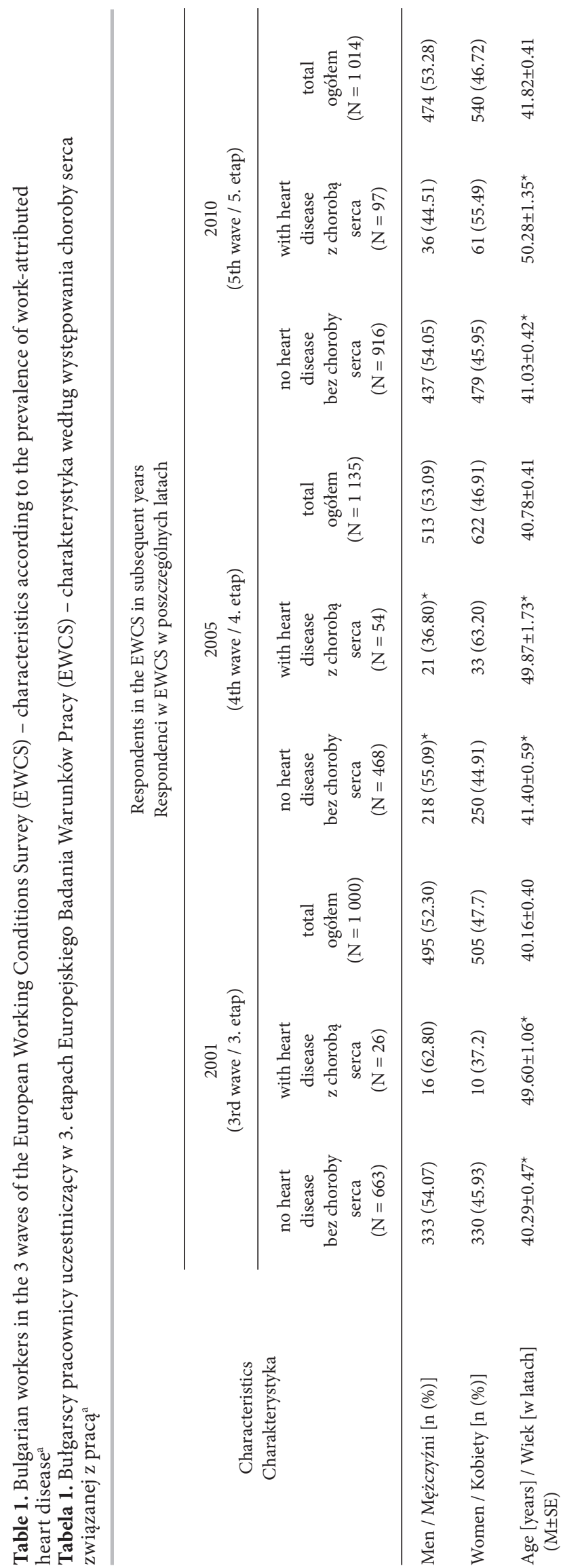




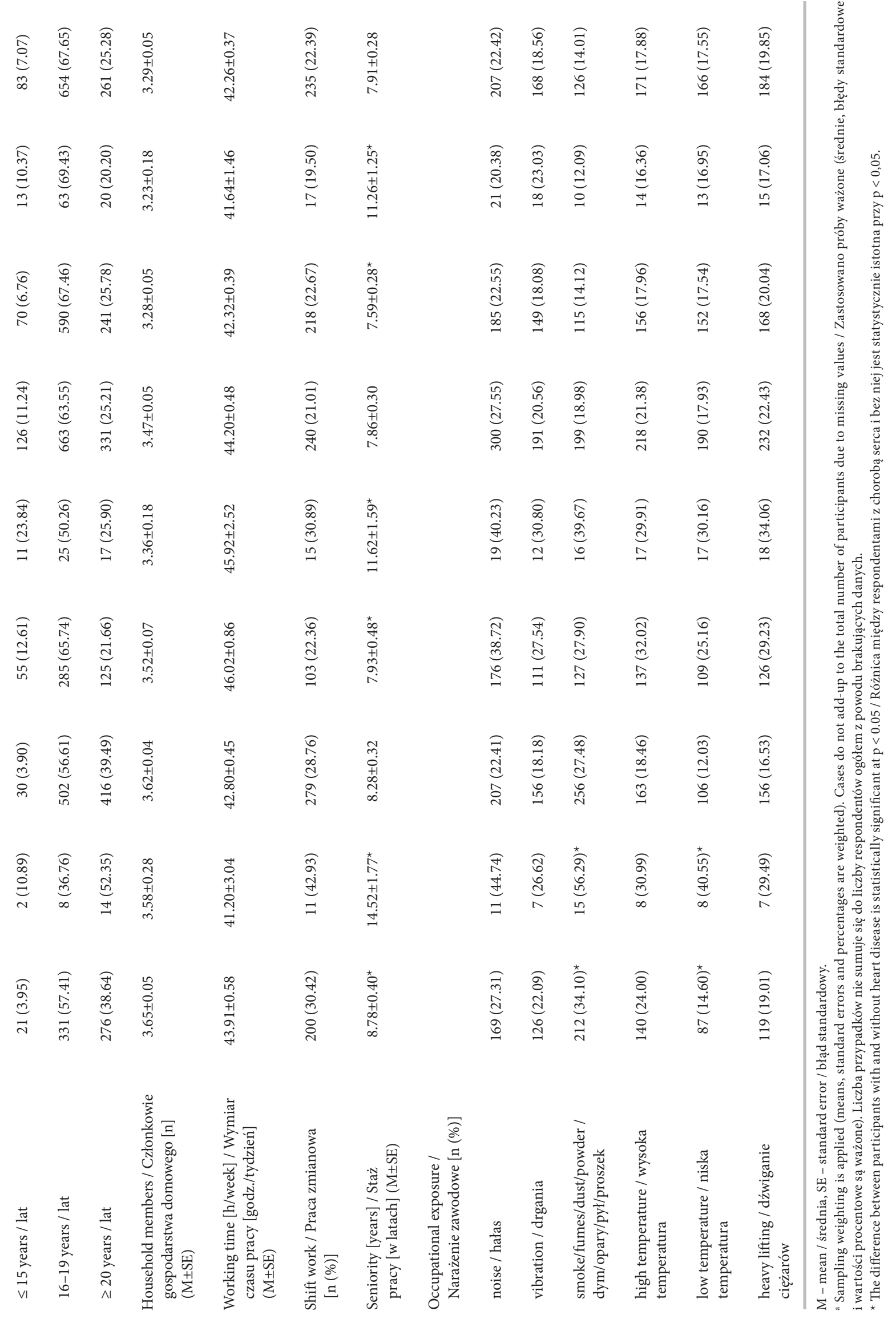




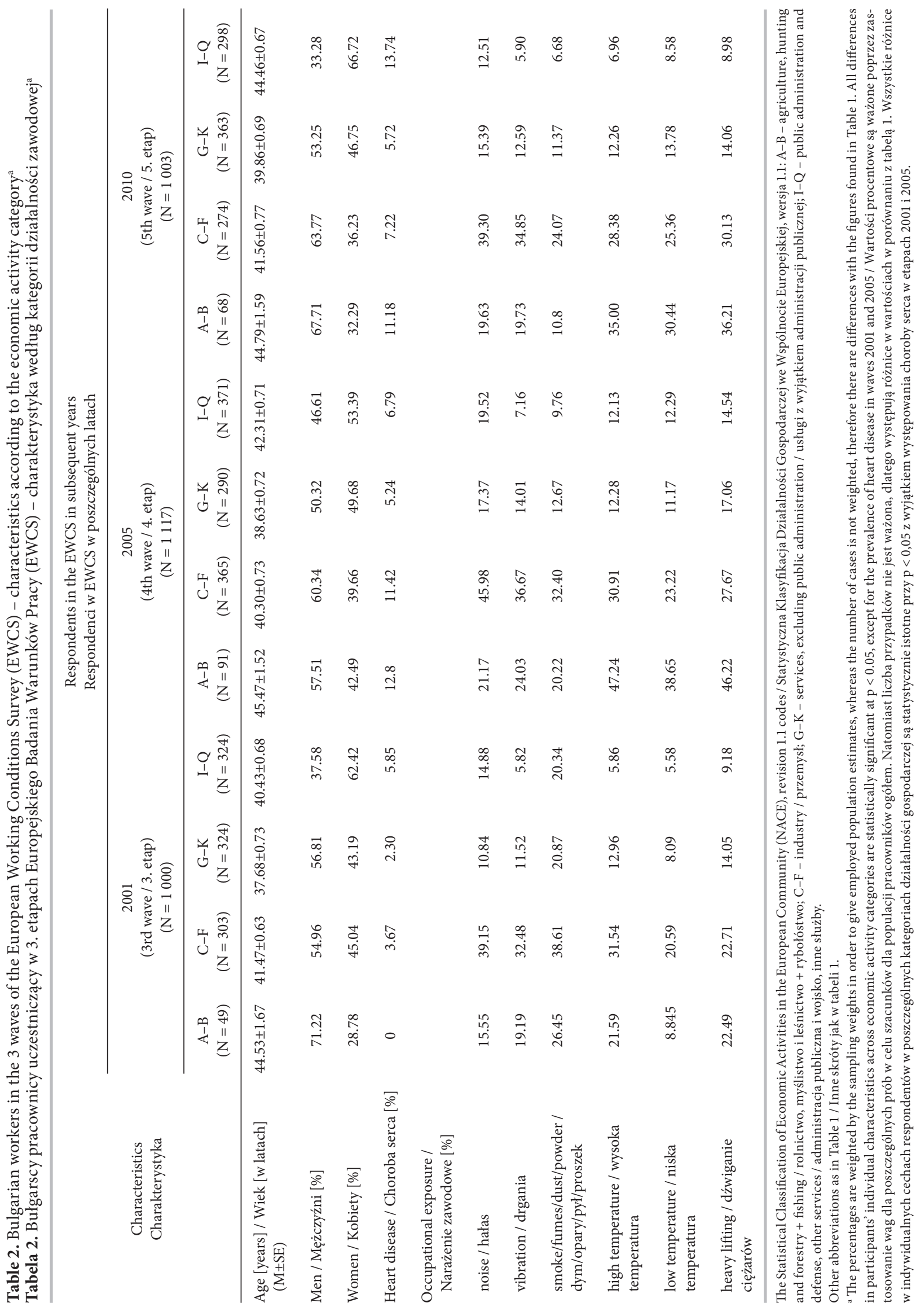


Table 3. Pooled relative risks (RR) of work-attributed heart disease associated with exposure to different physical and chemical occupational factors for at least 1/2 of the time at work, Bulgaria, in years 2001, 2005, and 2010 combined $^{\mathrm{a}}$

Tabela 3. Łączne względne ryzyko (RR) zawodowej choroby serca związanej z narażeniem na różne czynniki fizyczne i chemiczne w miejscu pracy przez co najmniej 1/2 czasu pracy w Bułgarii w latach 2001, 2005 i 2010 łącznie

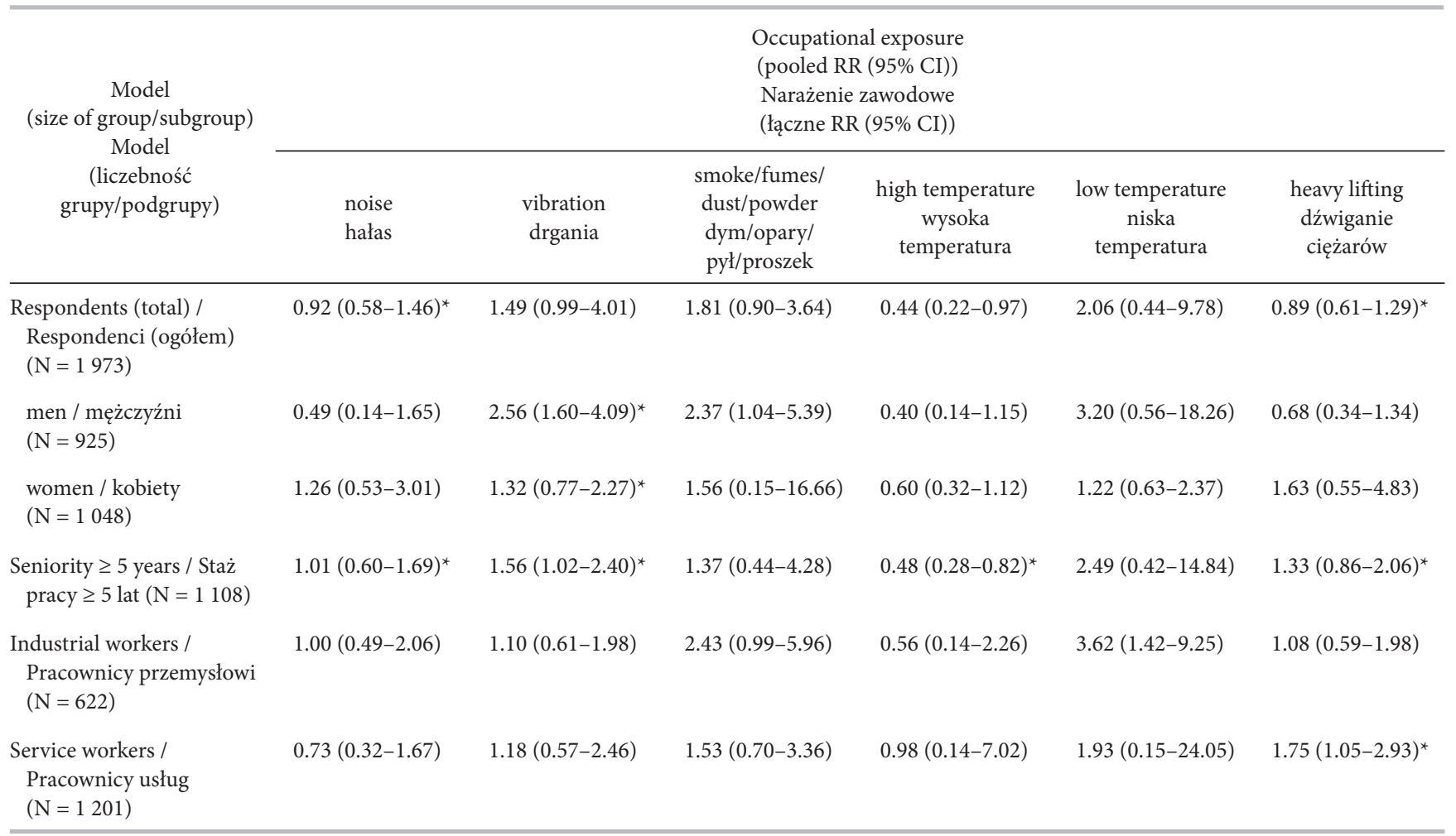

CI - confidence interval / przedział ufności.

a Sampling weighting is applied. Models are adjusted for age, gender, number of household members, age at which full-time education was finished, workweek hours, years of working for the current company/organization, shift work, and other co-exposures / Zastosowano próby ważone. W modelach wprowadzono poprawki na wiek, płeć, liczbę członków gospodarstwa domowego, wiek zakończenia nauki w pełnym wymiarze godzin, tygodniowy czas pracy, staż pracy u obecnego pracodawcy i narażenie na inne czynniki. * Confidence limit ratio: < 3 / Granica współczynnika ufności: <3.

remained fairly unchanged whereas noise exposure peaked in 2005 and dropped in 2010 to its rate in 2001. Low temperature exposure increased from $12.03 \%$ in 2001 to $17.55 \%$ in 2010 .

The proportion of workers reporting heart disease increased alarmingly from $3.6 \%$ in 2001 to $9 \%$ in 2005 and remained similar in 2010 (8.4\%) (Figure 2). According to the Table 1, those with heart disease were significantly older and had the longer length of service. Regarding occupational factors, the proportions of workers exposed to smoke/fumes/powder/dust and low temperatures were significantly higher among those with heart disease in 2001.

The Table 2 shows the distribution of participants' characteristics across different occupational categories. The proportion of people exposed to self-reported noise and vibration was highest among industrial workers, followed by those working in agriculture, hunting and forestry + fishing. Heart disease was generally most common in those categories, although in 2010 it peaked among public administration and service workers.

The Table 3 presents the results from multivariate models exploring the risk of work-attributed heart disease associated with exposure to different occupational factors for at least half of the time at work. Pooled results showed the higher risk of heart disease associated with self-reported noise exposure only among women (relative risk $(\mathrm{RR})=1.26$, 95\% confidence interval $(\mathrm{CI}): 0.53$ 3.01), but not men ( $R R=0.49,95 \%$ CI: $0.14-1.65)$. There were not significant differences between industrial and service workers. The only precise estimate, based on its CLR, was that for participants working in their current organization for $\geq 5$ preceding years, but it was very small ( $\mathrm{RR}=1.01,95 \% \mathrm{CI}$ : $0.60-1.69)$.

The relative risk for self-reported vibration exposure, on the other hand, was elevated and precise in several subgroups. It was higher among men $(\mathrm{RR}=2.56,95 \% \mathrm{CI}: 1.60-4.09)$ than women $(\mathrm{RR}=1.32$, 
95\% CI: 0.77-2.27). Among long-term workers it reached $\mathrm{RR}=1.56,95 \% \mathrm{CI}: 1.02-2.40$; it was elevated in both industrial and service workers, but the difference was not statistically significant.

\section{DISCUSSION}

Pooled results showed that working under loud self-reported occupational noise was associated with $26 \%$ of elevated risk of prevalent heart disease among women, and with $1 \%$ - among long-term workers, respectively. However, only the risk among long-term workers was considered precise with relatively narrow 95\% CI. Meta-analyses have found odds of hypertension to be odds ratio $(\mathrm{OR})_{\text {per } 5 \mathrm{~dB}}=1.14,95 \%$ CI: 1.01-1.29 [5], and, more recently, $\mathrm{OR}_{\text {per } 5 \mathrm{~dB}}=1.18,95 \% \mathrm{CI}=1.10$ 1.27 [6]. Tomei et al. also estimated the significant increase in mean blood pressure and prevalence of hypertension and ECG abnormalities for workers exposed to $92.2 \pm 6.5 \mathrm{~dB}$ in comparison to those exposed to $85.2 \pm 6.7 \mathrm{~dB}$ and $62.2 \pm 28.7 \mathrm{~dB}$ [7]. Results for ischemic heart disease also point towards an increased risk, associated with occupational noise $[8,9]$.

With respect to the gender differences we observed, other authors have, in similar vein, found more pronounced risk among women. In the study of Stokholm et al. the risk was $\mathrm{RR}=1.17,95 \% \mathrm{CI}: 1.09-1.26$ among women and $\mathrm{RR}=1.06,95 \% \mathrm{CI}$ : 0.98-1.14 among men [31]. In that of Kersten and Backé men were, in fact, not found to be at risk [32]. Gan et al., on the contrary, reported statistically significantly elevated odds of coronary heart disease only among male workers [8].

A statistically significant relationship between selfreported occupational noise and heart disease was found in a nationally-representative cross-sectional survey among 6341 Bulgarian workers, but, surprisingly, the authors considered it to be a spurious one due to the lack of "logical link with noise as a factor of the occupational environment" [10]. Furthermore, the effects were not adequately adjusted for other covariates and the authors used data collected only in 1 wave (2010) [10]. A case-control study including nearly 3000 blue- and white-collar workers looked at gender differences in the effect on myocardial infarction and found an elevated $\mathrm{OR}_{\text {unadjusted }}=4.014$, 95\% CI: 0.843-19.105 among women and non-elevated $\mathrm{OR}_{\text {unadjusted }}=0.680,95 \%$ CI: $0.379-1.220$ among men [11]. Overall, very few studies globally compared noise effects between men and women, since the focus is mainly on machine and industrial noise found among blue-collar workers, who are mostly male. Thus women and those exposed to noise from social sources (e.g., teachers) are excluded.

Exposure to self-reported occupational vibration, unlike noise, was associated with the elevated risk of prevalent heart disease in several subgroups. It was higher among men (156\%) than women (32\%), and reached $56 \%$ in long-term workers, $10 \%$ among industrial and $18 \%$ among service workers. The pooled estimates had narrow 95\% CIs among men, women, and long-term workers and they were statistically significant among men and long-term workers. In other countries, the prevalence of ischemic heart disease among exposed miners was $11 \%$ vs. $6 \%$ in the non-exposed controls [16], Idzior-Walus found that men exposed to loud noise (105-116 dB) and vibration had higher mean blood pressure and percentage of hypertension [17], Björ et al. found OR $=1.06,95 \%$ CI: 1.1-2.4 for incident myocardial infarction among male workers exposed to hand-arm and whole-body vibration [15]. In Bulgaria, Tzvetkov and Tzatcheva observed higher prevalence of hypertension and ischemic heart disease among both male and female blue-collar workers exposed to vibration during the period 1982-1987, in comparison to non-exposed white-collar workers [18]. In contrast to our findings, Dimitrova and Karaslavova reported $\mathrm{OR}_{\text {unadjusted }}=0.830,95 \%$ CI: $0.442-1.557$ among exposed men and $\mathrm{OR}_{\text {unadjusted }}=11.39,95 \% \mathrm{CI}$ : $0.751-$ 172.7 among women [11]. No effect at all was reported by Stefanova et al. [10].

The literature on gender differences in hand-arm and whole-body vibration is controversial. According to some authors, women are more sensitive to vibration and perceive their exposure as higher $[33,34]$; others suggested that the impact of whole-body vibration is stronger on male heart rate variability [35], and that nighttime train vibration is associated with a slightly stronger increase in the heart rate in the delayed response of men [36]. Further comparisons with our findings are hindered not only by the few occupational epidemiology studies overall but also by the different populations under investigation (i.e., white/blue-collar, men/women). We cannot rule out the possibility that the quality of reporting and type of vibration sources differed between men and women since blue-collar workers are mostly male whereas workers in public administrations, for example, were mostly female.

Analyses stratified by occupational category lacked statistical power, since economic activities could not be coded for all participants and the number of people ex- 
posed to self-reported noise and vibration and having heart disease was very low in some of those categories.

Secondary findings were the elevated risks among workers exposed to smoke/fumes/dust/powder, low temperatures and heavy lifting; however, those effects were not precise and stable. Counterintuitively, high temperatures were consistently associated with the lower risk of heart disease, which could be due to some residual confounding, lack of precision of the questionnaire item or to survivor effect.

\section{Strengths and limitations}

The strengths of this study lie in its relatively large sample, nationally-representative design, and the fact that it covers a 10-year period (2001-2010). It is also a population-based study, which is rare in the field of occupational hygiene. It does not discard white-collar workers and women and adjusts the effects of self-reported noise and vibration for each other and for important demographics and other work-related variables.

Several limitations are also acknowledged. Causeand-effect relationships between exposure and outcome cannot be discerned owing to the cross-sectional design of the EWCS. Nevertheless, cross-sectional studies in noise hygiene are justifiable, since they comply with many of the important criteria for causality in epidemiology [37]. The so called healthy worker/survivor effect [38] is another issue, which leads to underestimation of the risk.

Self-reports of heart disease and occupational exposure may be scrutinized for biasing the results towards the null. While this is true, there is good compatibility between self-reported and objective ischemic heart disease/hypertension [39-41]. Self-reported exposure is another issue. Due to that we could not estimate precise exposure-response relationships. The questions we used, however, appear to be valid proxies for the actual exposure level. We compared noise and vibration selfreported by some of the blue-collar workers with jobexposure measurements. It also bears noting that a nationally-representative survey among Bulgarian workers conducted by the Ministry of Labour and Social Policy in 2010 showed that there was good compatibility, overall, between objectively measured and self-reported exposures derived from the same questions, although there were disparities with respect to noise exposure reported by teachers, and with respect to perceived temperature by those working outside [10]. Therefore, a national-representative job-exposure matrix for noise and vibration should be developed in Bulgaria.
Some risk estimates were not statistically significant but they were still treated as substantive effects because their 95\% CIs were precise in terms of the CLR, which is considered to be more durable and relevant in epidemiological research [29] and noise hygiene, where the mechanistical interpretation of p-values is discouraged [42].

Finally, an issue may be raised about the lack of information on behavioral and individual determinants of the CVD (e.g., heredity, diet, physical activity, obesity, stress, sleep quality, etc.). Those would be important covariates if we were interested in the direct effect of self-reported noise and vibration. Given that we only looked at the total effect, those covariates were not necessary, as indicated by the directed acyclic graph (DAG) causal model.

Self-reported occupational noise and vibration were still alarmingly common among Bulgarian workers in 2015 (28.8\% and $23.5 \%$, respectively) [3], but the research interest in their cardiovascular effects is low. Moreover, noise generated by human speech is not officially recognized as a cardiovascular risk factor [10]. Globally, there is a dearth of evidence regarding the effects of noise and vibration on the CVD among female and white-collar workers. Therefore, despite the limitations of this study, it can serve as a basis for future research.

\section{CONCLUSIONS}

Based on self-reports, the risk of prevalent heart disease attributed to occupational noise exposure was elevated only among female, long-term, and blue-collar workers, but the risk estimate was precise only for long-term workers. Self-reported vibration exposure, on the other hand, was consistently associated with the elevated risk of heart disease in the case of all workers, and the effect was strongest in the case of men.

\section{ACKNOWLEDGEMENTS}

We are grateful to the European Foundation for the Improvement of Living and Working Conditions and to the UK Data Service for providing the data from the EWCS. However, neither the European Foundation for the Improvement of Living and Working Conditions, nor the UK Data Service, bears any responsibility for the analysis or interpretation of that data. We received no funding and do not have any relationships which could be construed as potential conflict of interest. 


\section{REFERENCES}

1. Mendis S, Puska P, Norrving B, editors. Global atlas on cardiovascular disease prevention and control. Geneva: World Health Organization; 2011.

2. World Health Organization. A global brief on hypertension: Silent killer, global public health crisis. Geneva: The Organization; 2013.

3. European Foundation for the Improvement of Living and Working Conditions (Eurofound) [Internet]. The Foundation; 2016 [cited 2015 Dec 22]. Sixth European Working Conditions Survey 2015. Available from: http:// www.eurofound.europa.eu/surveys/data-visualisation/ sixth-european-working-conditions-survey-2015.

4. Recio A, Linares C, Banegas JR, Díaz J. Road traffic noise effects on cardiovascular, respiratory, and metabolic health: An integrative model of biological mechanisms. Environ Res. 2016;146:359-70, http://dx.doi.org/ 10.1016/j.envres.2015.12.036.

5. Van Kempen EE, Kruize H, Boshuizen HC, Ameling CB, Staatsen BA, de Hollander AE. The association between noise exposure and blood pressure and ischemic heart disease: A meta-analysis. Environ Health Perspect. 2002;110:307-17.

6. Stokholm ZA. Occupational noise exposure, physiological stress, and cardiovascular health [dissertation]. Aarhus: Aarhus University; 2013.

7. Tomei G, Fioravanti M, Cerratti D, Sancini A, Tomao E, Rosati MV, et al. Occupational exposure to noise and the cardiovascular system: A meta-analysis. Sci Total Environ. 2010;408:681-9, http://dx.doi.org/10.1016/j.scitotenv.2009.10.071.

8. Gan WQ, Davies HW, Demers PA. Exposure to occupational noise and cardiovascular disease in the United States: The National Health and Nutrition Examination Survey 1999-2004. Occup Environ Med. 2011;68:183-90, http://dx.doi.org/10.1136/oem.2010.055269.

9. Virkkunen H, Kauppinen T, Tenkanen L. Long-term effect of occupational noise on the risk of coronary heart disease. Scand J Work Environ Health. 2005;31:291-9, http://dx.doi.org/10.5271/sjweh.885.

10. Stefanova M, Haralampiev K, Tomova T, Kalfova E, Neykov I, Gospodinova Z, et al. [Report: National working conditions survey in Bulgaria] [Internet]. Sofia: General Labour Inspectorate Executive Agency; 2012 [cited 2015 Dec 22]. Available from: http://projects.gli.government.bg/index.php? $\bmod =$ content\&show=43. Bulgarian.

11. Dimitrova T, Karaslavova E. [Vibrations in the working environment and risk of acute myocardial infarction]. Med Rev. 2008;44:54-7. Bulgarian.
12. Goranova L. [Main parameters and quantities for characterizing vibration]. In: Tzvetkov D, Angelova M, editors. [Infrasound, ultrasound, noise and vibration]. Sofia: Medizina i Fizkultura; 2007. p. 148-52. Bulgarian.

13. Mitrev N. [Impact of hand-arm vibrations on the organism]. In: Tzvetkov D, Angelova M, editors. [Infrasound, ultrasound, noise and vibration]. Sofia: Medizina i Fizkultura; 2007. p. 184-201. Bulgarian.

14. Ivanovich $\mathrm{E}$. [Impact of whole-body vibrations on the organism]. In: Tzvetkov D, Angelova M, editors. [Infrasound, ultrasound, noise and vibration]. Sofia: Medizina i Fizkultura; 2007. p. 201-15. Bulgarian.

15. Björ B, Burström L, Nilsson T, Reuterwall C. Vibration exposure and myocardial infarction incidence: The VHEEP case-control study. Occup Med (Lond). 2006;56(5): 338-44, http://dx.doi.org/10.1093/occmed/kq1024.

16. Tamaian L-D, Cocarla A. Occupational exposure to vibration and ischemic heart disease. J Occup Health. 1998;40:73-6, http://dx.doi.org/10.1539/joh.40.73.

17. Idzior-Walus B. Coronary risk factors in men occupationally exposed to vibration and noise. Eur Heart J. 1987; 8:1040-6.

18. Tzvetkov D, Tzatcheva N. Hypertension and ischemic heart disease morbidity with temporary disability among workers exposed to vibration. Noise Vibration Bull. 1990;10:540-2.

19. Fang SC, Cassidy A, Christiani DC. A systematic review of occupational exposure to particulate matter and cardiovascular disease. Int J Environ Res Public Health. 2010;7(4):1773-806, http://dx.doi.org/10.3390/ ijerph7041773.

20. Hannerz H, Holtermann A. Ischaemic heart disease among workers in occupations associated with heavy lifting. Int J Occup Med Environ Health. 2016;29(1): 129-36.

21. Price AE. Heart disease and work. Heart. 2004;90(9): 1077-84, http://dx.doi.org/10.1136/hrt.2003.029298.

22. Kang MY, Park H, Seo JC, Kim D, Lim YH, Lim S, et al. Long working hours and cardiovascular disease: A meta-analysis of epidemiologic studies. J Occup Environ Med. 2012;54(5):532-7, http://dx.doi.org/10.1097/ JOM.0b013e31824fe192.

23. Virkkunen H, Härmä M, Kauppinen T, Tenkanen L. The triad of shift work, occupational noise, and physical workload and risk of coronary heart disease. Occup Environ Med. 2006;63(6):378-86, http://dx.doi.org/10.1136/ oem.2005.022558

24. European Foundation for the Improvement of Living and Working Conditions (Eurofound) [Internet]. Colchester, Essex: UK Data Service; 2013 [cited 2015 Dec 22]. 
European working conditions survey integrated data file, 1991-2010. Available from: http://dx.doi.org/10.5255/ UKDA-SN-7363-1.

25. Goranova L, Ivanivich E, Paunov I. [Vibration factor in industry and transportation in Bulgaria]. In: Tzvetkov D, Angelova M, editors. [Infrasound, ultrasound, noise and vibration]. Sofia: Medizina i Fizkultura; 2007. p. 173-83. Bulgarian.

26. Goranova L, Ivanivich E, Paunov I. [Noise factor in industry and transportation in Bulgaria]. In: Tzvetkov D, Angelova M, editors. [Infrasound, ultrasound, noise and vibration]. Sofia: Medizina i Fizkultura; 2007. p. 94-102. Bulgarian.

27. Cummings P. Methods for estimating adjusted risk ratios. Stata J. 2009;9(2):175-96.

28. Textor J, Hardt J, Knüppel S. DAGitty: A graphical tool for analyzing causal diagrams. Epidemiology. 2011;5(22): 745, http://dx.doi.org/10.1097/EDE.0b013e318225c2be.

29. Doi SA, Barendregt JJ, Khan S, Thalib L, Williams GM. Advances in the meta-analysis of heterogeneous clinical trials I: The inverse variance heterogeneity model. Contemp Clin Trials. 2015;45(Pt A):130-8, http://dx.doi. org/10.1016/j.cct.2015.05.009.

30. Poole C. Low p-values or narrow confidence intervals: Which are more durable? Epidemiology. 2001;12(3):291-4, http://dx.doi.org/10.1097/00001648-200105000-00005.

31. Stokholm ZA, Bonde JP, Christensen KL, Hansen AM, Kolstad HA. Occupational noise exposure and the risk of hypertension. Epidemiology. 2013;24(1):135-42, http:// dx.doi.org/10.1097/EDE.0b013e31826b7f76.

32. Kersten N, Backé E. Occupational noise and myocardial infarction: Considerations on the interrelation of noise with job demands. Noise Health. 2015;17:116-22, http:// dx.doi.org/10.4103/1463-1741.153403.

33. Shibata N, Ishimatsu K, Maeda S. Gender difference in subjective response to whole-body vibration under standing posture. Int Arch Occup Environ Health. 2012;85(2): 171-9, http://dx.doi.org/10.1007/s00420-011-0657-0.

34. Jeon B-H, Ajovalasit M, Giacomin J. Effects of gender differences on the subjective perceived intensity of steer- ing wheel rotational vibration based on a multivariate regression model. Int J Ind Ergon. 2009;39:736-43, http:// dx.doi.org/10.1016/j.ergon.2009.02.010.

35. Yau HK. Gender differences of human response under vibration condition. IAENG transactions on engineering technologies. Dordrecht: Springer; 2013. p. 301-8, http:// dx.doi.org/10.1007/978-94-007-5651-9_22.

36. Croy I, Smith MG, Waye KP. Effects of train noise and vibration on human heart rate during sleep: An experimental study. BMJ Open. 2013;3(5):e002655, http:// dx.doi.org/10.1136/bmjopen-2013-002655.

37. Niemann $H$, Bonnefoy $X$, Braubach $M$, Hecht $K$, Maschke C, Rodrigues C, et al. Noise-induced annoyance and morbidity results from the pan-European LARES study. Noise Health. 2006;8:63-79, http:// dx.doi.org/10.4103/1463-1741.33537.

38. Arrighi HM, Hertz-Picciotto I. The evolving concept of the healthy worker survivor effect. Epidemiology. 1994;5(2):189-96, http://dx.doi.org/10.1097/00001648 199403000-00009.

39. Lampe FC, Walker M, Lennon LT, Whincup PH, Ebrahim S. Validity of a self-reported history of doctor-diagnosed angina. J Clin Epidemiol. 1999;52(1):73-81, http:// dx.doi.org/10.1016/S0895-4356(98)00146-2.

40. Oksanen T, Kivimäki M, Pentti J, Virtanen M, Klaukka T, Vahtera J. Self-report as an indicator of incident disease. Ann Epidemiol. 2010;20(7):547-54, http://dx.doi. org/10.1016/j.annepidem.2010.03.017.

41. Molenaar EA, van Ameijden EJ, Grobbee DE, Numans ME. Comparison of routine care self-reported and biometrical data on hypertension and diabetes: Results of the Utrecht Health Project. Eur J Public Health. 2007;17(2):199-205, http://dx.doi.org/10.1093/eurpub/ckl113.

42. Babisch W. Transportation noise and cardiovascular risk. Review and synthesis of epidemiological studies. Dose-effect curve and risk estimation [Internet]. Berlin: WaBoLu-Hefte, Umweltbundesamt; 2006 [cited 2016 Jan 12]. Available from: http://www.bruit.fr/images/ stories/pdf/babisch_transportation_noise_cardiovascular_risk.pdf.

This work is available in Open Access model and licensed under a Creative Commons Attribution-NonCommercial 3.0 Poland License / Ten utwór jest dostępny w modelu open access na licencji Creative Commons Uznanie autorstwa - Użycie niekomercyjne 3.0 Polska - http://creativecommons.org/ licenses/by-nc/3.0/pl/deed.en. 